the first time in public. The sending station was the South Tower of the Crystal Palace, the wave-length employed being 8.3 metres. The quality of the pictures was naturally much inferior to those with which the present-day viewer is familiar : only 120 scanning lines being used as compared with the 400 lines now employed by the British Broadcasting Corporation. The projected picture was twelve feet by nine feet and could be clearly seen by everyone in this large theatre. It was illuminated by a highintensity arc lamp. The programme included the transmission of fashion plates of ladies hats; the various coloured flowers were quite brilliant and the gaily and variegated headgear sometimes used by officers abroad came out very distinctly. A coloured cartoon of Popeye the Sailor caused much amusement. Colour television is still in the early stages of development, but the transmission was very successful and the unexpected show was well received by the spectators.

THE present apparatus used by Baird Television transmits a 120-line picture, the scanning at both transmitter and receiver being by mechanical means. The transmitter consists of a mirror drum with twenty mirrors inclined at different angles revolving at 6,000 r.p.m. These mirrors reflect the scene to be transmitted through a lens, causing an image to be formed on a rotating disk with twelve concentric slots at different distances from its periphery. By this means the field given by the 20 -line drum is interlaced six times to give a 120-line picture repeated twice for each revolution of the disk. Each of the slots is covered with a light filter, blue-green and red being used alternately, the effect of this being to transmit alternate lines of the picture corresponding to a blue-green image and a red image. At the receiving station a similar device is employed, the rotating drum in this case being much larger (12 in. in diameter in place of the 8 in. at the transmitter). Light from a high intensity arc lamp is concentrated on the moving aperture in the disk and yields sufficient light to fill a screen $12 \mathrm{ft} . \times 9 \mathrm{ft}$.

\section{Archæological Expedition to Syria}

Sir Leonard AND LAdy Woolley, it is announced, are leaving England for Syria, where the British Museum Expedition under Sir Leonard's direction will resume excavations immediately at Tell Atchana in the Amk plain on the Orontes, North Syria. This site, as has been shown by the previous seasons' excavations, has surpassed anticipation in its importance for the cultural relations of Asia and the eastern Mediterranean at an early date. The results which have been obtained already, as has recently been demonstrated by Sir Arthur Evans, when correlated with the information now accruing from the excavations of French archæologists at the Syrian site of Ras Shamra, have already thrown light on chronological and other problems of the Minoan civilization of Crete, as well as indicated the extent of Cretan influence on Asianic culture. The work of the British Museum Expedition in the coming season will be devoted mainly to the further exploration and clearing of the palace, of which, as was pointed out by Sir Leonard Woolley in his recent lecture before the Royal Institution (see Nature, January 29, p. 194), the architecture both in material and in style is as essentially Cretan as the painted pottery discovered on this site. It is hoped that additions to knowledge of political and social conditions of the time may accrue from further discoveries of the cuneiform tablets, from which it has already been established that the building is a royal palace dating to about 1600 B.c. Sir Leonard Woolley will be accompanied by Mr. P. W. MurrayThreepland, who will again act as his assistant, and by Mr. Ralph Lavers, acting as architect of the expedition, who has had previous experience of archæological investigation at Tell el-Amarna in Egypt and in Crete.

\section{Dynamic Ecology of Sand Dunes}

AT the Friday evening discourse at the Royal Institution on February 4, Prof. E. J. Salisbury discussed "Plants of the Sand Dunes and Why They Grow There". Sand dunes are a unique type of habitat. They depend on plants for their develop. ment. They show such rapid changes that the dynamic character of communities of plants is here forced upon our notice. Moreover, because a sequence in space corresponds to the sequence of development in time, the nature of these changes can be ascertained with certainty. The pioneer plants are rapidly growing grasses equipped with leaves which are so constructed that they automatically adjust their rate of water loss to the water income. Further, these grasses can endure burial by sand and are indeed stimulated thereby to grow through to the new surface. All these features enable them to endure the desert-like conditions and mobility of their rooting medium. Although the water content of young dunes is less than four per cent, it is maintained at a com. paratively constant though low level owing to the occurrence in sunny weather of conditions that promote internal deposition of dew within the dunes. Sand dunes thus illustrate in a striking manner the dynamic character of vegetation and the fallacy of the widespread belief that to preserve a natural area all that is necessary is to leave it alone.

\section{Dublin Zoo and Bird Sanctuary}

Ax the annual meeting of the Royal Zoological Society of Ireland, held at Dublin on January 26, Lord HolmPatrick was re-elected president, Dr. J. Agar Matson honorary secretary, Mr. Cecil Pim honorary treasurer. It was announced that Dr. B. B. Farrer, superintendent and secretary of Dublin Zoo for the past twenty-six years, is retiring. Dr. Matson reported that during the year 1937 there was an increased attendance at the $Z$ oo of 152,173 visitors as against 151,109 in 1936 , receipts having increased from $£ 3,561$ to $£ 3,661$. Membership increased by 54. The Government's grant of $£ 1,000$ was continued and various improvements and works are being carried out, the new bear enclosure now 
nearing completion. More than $\mathbf{1 5 2 0}$ was spent purchasing and transporting animals like penguins, sea-lion, wolves, wallabies and laughing jackass; but owing to various restrictions some valuable animals offered could not be accepted. The meeting was followed by a lecture by Father P. J. Kennedy, a well-known local ornithologist, on the birds of Phœnix Park. Father Kennedy gave a detailed history of the formation of the Park until it was turned into a bird sanctuary in 1937, its trees, shrubs, lakes and ponds being so valuable. The birds he then discussed were the 83 species which have been observed in the Park, and included grey crow, rook, jackdaw, magpie, jay, starling, greenfinch, goldfinch (which he said is increasing), chaffinch, bullfinch, linnet, crossbill, yellow-hammer, skylark, pied wagtail, tree-creeper, black-cap and spotted fly-catcher.

\section{The Maidenhair Tree}

THE origin of the curious generic name, Ginkgo biloba, of this tree is very fully discussed, with reference to original Chinese and Japanese descriptions, by Prof. A. C. Moule in T'Oung Pao, 23, published by the firm of E.J. Brill, Leyden. The name seems to be due to Engelbert Kaempfer, a German naturalist (1651-1716) who was in Japan apparently about 1690-2. The Kaempfer MSS. are stated by Larousse to be preserved in the Museum of Botany at Leyden where, however, search has failed to find them; Prof. Moule, however, through Sir Albert Seward, has traced the original entries of Kaempfer in his manuscripts in the British Museum. These seem to make it clear that when Kaempfer, some eighteen years later, published the names from his original descriptions, he deciphered incorrectly an original manuscript entry of Sankyo in the form of Ginkgo, where it is difficult to decide whether the ' $g$ ' is a slip in transcription or a misprint that has been overlooked. Thus "this strange word, which is unpronounceable and probably ought never to have existed, has been for nearly two centuries and, I suppose, will always be the generic name of this beautiful and interesting tree". There is a very full discussion of the numerous Chinese names of this tree which are all either descriptive names of two or more words or are frankly borrowed from other trees, suggesting that the tree was not known in northern China during the centuries when the Chinese classical civilization and language were being formed. This may confirm the view of $F$. N. Meyer and others that the tree is indigenous in the forests of Chê-Chiang, but in favour of the other view that it survives only in cultivation is the fact that no large specimens have been reported from forests. There is an interesting discussion of its fire-resisting qualities, which were exemplified by the recovery of many trees in Tokyo after the big fire that followed the earthquake in 1923 ; popular testimony thus made a huge Ginkgo tree largely responsible for the survival of the great temple of Kwannon at Asakasa; it was believed that the tree literally rained moisture on the roof, and also protected it against burning fragments carried in the wind.

\section{Health Committee of the League of Nations}

Ar the twenty-fifth session of the Health Committee of the League of Nations, April 26-May 1 (G. Allen and Unwin, League of Nations Department, 40 Museum St., Iondon, W.C.I : Report to the Council on the Work of the 25th Session of the Health Committee, 1s.) the next three-year programme was discussed and approved. Among the permanent activities of the Committee, its work on biological standards is far from being completed. New therapeutic agents gain acceptance with the advance of science and require assay in terms of some common standard, and other standards already adopted are either open to improvement or, being composite, are liable to be replaced sooner or later by the active substance in pure form, apart from the possibility of physical or chemical methods replacing the biological method. Forty-one countries have adopted or are about to adopt the international standards recommended by the Permanent Com. mission on Biological Standards, and thirty-one Governments have established or are about to establish national centres, thus simplifying the task of the central institutes at Copenhagen and Hamp. stead. For drugs like digitalis, pituitary extract and arsphenamine, no insuperable difficulties are anticipated in preparing national standards, but it is expected that for serological standards the Copenhagen Institute will have to continue to supply international standard sera to most of the national centres. The standardization of anti-anthrax serum, examined in 1925, requires further investigation in collaboration with the Institute at Budapest and Bucharest. Further study of the standardization of anti-swineerysipelas serum is also necessary as well as con. sideration of changes in the international standards for tuberculin and staphylococcus anti-toxin. The standardization of anti-snake venom sera, pharmacological standards, as well as those for vitamins and sex hormones, also fall within the next three-year programme of the Commission. Other matters in the programme of the Committee are leprosy, rural hygiene, housing, physical education, nutrition and opium and other dangerous drugs.

\section{Dietetics and Social Problems}

THE problem to what extent a wise social policy, taking into account modern scientific developments in the field of nutrition, can help to raise the standard of living in certain countries, or for certain categories of population, which at present suffer from undernourishment or malnutrition, is being investigated by the International Labour Office, assisted by a Committee of Experts which met at Geneva on April 9-10, under the chairmanship of Mr. Bramsnaes. This committee discussed the efforts of the International Labour Office to demonstrate the progress of dietetic science and its importance in regard to social questions. Special stress was laid on the necessity of distinguishing between the physiological, health and social aspects of the problem, and it was agreed that the studies should be studied simultaneously in various countries according to a uniform 